\title{
"Bank-centric nature of the financial system of Ukraine: analysis of the current situation"
}

\begin{tabular}{|c|c|}
\hline AUTHORS & $\begin{array}{l}\text { Serhiy Frolov (D https://orcid.org/0000-0001-9374-7274 } \\
\text { R http://www.researcherid.com/rid/C-1635-2018 } \\
\text { Fathi Shukairi (D https://orcid.org/0000-0003-0381-4707 }\end{array}$ \\
\hline ARTICLE INFO & $\begin{array}{l}\text { Serhiy Frolov and Fathi Shukairi (2020). Bank-centric nature of the financial } \\
\text { system of Ukraine: analysis of the current situation. Banks and Bank Systems, } \\
\text { 15(3), 184-198. doi:10.21511/bbs.15(3).2020.16 }\end{array}$ \\
\hline DOI & http://dx.doi.org/10.21511/bbs.15(3).2020.16 \\
\hline RELEASED ON & Wednesday, 07 October 2020 \\
\hline RECEIVED ON & Friday, 14 August 2020 \\
\hline ACCEPTED ON & Wednesday, 30 September 2020 \\
\hline LICENSE & $\begin{array}{l}(c) E Y \text { EY } \\
\text { This work is licensed under a Creative Commons Attribution } 4.0 \text { International } \\
\text { License }\end{array}$ \\
\hline JOURNAL & "Banks and Bank Systems" \\
\hline ISSN PRINT & $1816-7403$ \\
\hline ISSN ONLINE & $1991-7074$ \\
\hline PUBLISHER & LLC "Consulting Publishing Company "Business Perspectives" \\
\hline FOUNDER & LLC "Consulting Publishing Company "Business Perspectives" \\
\hline
\end{tabular}

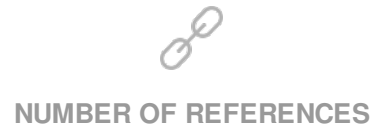

31

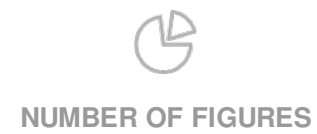

12
NUMBER OF TABLES

0

(C) The author(s) 2021. This publication is an open access article. 


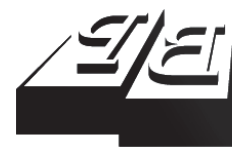

\section{BUSINESS PERSPECTIVES}

LLC "CPC "Business Perspectives" Hryhorii Skovoroda lane, 10, Sumy, 40022, Ukraine www.businessperspectives.org
Received on: $14^{\text {th }}$ of August, 2020 Accepted on: $30^{\text {th }}$ of September, 2020 Published on: $7^{\text {th }}$ of October, 2020

(C) Serhiy Frolov, Fathi Shukairi, 2020

Serhiy Frolov, Dr., Professor, Head of the Department of Finance of Business Entities and Insurance, University of Customs and Finance, Ukraine.

Fathi Shukairi, Ph.D. Student, University of Customs and Finance, Ukraine; National Oil Corporation, Libyan Arab Jamahiriya.
This is an Open Access article, distributed under the terms of the Creative Commons Attribution 4.0 International license, which permits unrestricted re-use, distribution, and reproduction in any medium, provided the original work is properly cited.

Conflict of interest statement: Author(s) reported no conflict of interest
Serhiy Frolov (Ukraine), Fathi Shukairi (Libyan Arab Jamahiriya)

\section{BANK-CENTRIC NATURE OF THE FINANCIAL SYSTEM OF UKRAINE: ANALYSIS OF THE CURRENT SITUATION}

\begin{abstract}
The formation and functioning of the country's financial system depend on many factors, both endogenous and exogenous. The economic system of a country, as a higherorder system in relation to the financial one, underlies the development of the financial system model. The existing model of the financial system becomes significant in the context of its impact on economic processes in the country. The main purpose of the empirical analysis is to confirm the thesis about the signs of the bank-centricity of the Ukrainian financial market. The share of assets of financial intermediaries in GDP is determined, which indicates a significant decrease in the share of assets of all financial intermediaries in Ukraine. Analysis of the loan-to-deposit ratio in the banking system of Ukraine shows that the deposit base was far smaller than the size of loans throughout the analyzed period. Analysis of non-performing loans by economic sectors shows that the largest share of NPLs is formed in the corporate sector of the economy. Analysis of the structure of banks' assets, taking into account their owners, shows that at the end of the analyzed period the share of state-owned banks' assets increased significantly. Thus, having analyzed the functioning of the banking system of Ukraine, one can conclude about the bank-centric nature of Ukraine's financial system.
\end{abstract}

Keywords financial systems, bank-centric, banking system

JEL Classification G18, G21, E44, E58

\section{INTRODUCTION}

In advanced market economies, the concepts of "financial system" and "financial market" are considered as analogues. In Ukraine, they differ, since the financial market is considered part of the financial system. This is due to the important role of public finance and a certain imbalance in their direction. The development of the financial market reflects the flexibility of the financial system and the speed with which it can adapt to changes in the economic and political life of the country, as well as to various processes taking place outside of it (Nikolyshyn \& Zizyak, 2014). Its state and prospects for its functioning are influenced by the state of public finance, the financial position of economic entities in the real sector and the state of financial intermediaries. The financial market in Ukraine is just emerging. "Soundness of banks along with the ease of access to loans and a low level of confidence in national banking system are the main reasons of instability in financial market in Ukraine" (Slav'yuk, Shkvarchuk, Kondrat, 2017). At the same time, the low level of global competitiveness in Ukraine is largely a consequence of the underdevelopment of the financial market (Stetsko, 2016). In the process of analyzing the current situation and identifying trends in its further development, it should be borne in mind that the financial market itself is a multilevel system with a complex internal structure, "as a system of interconnected segments, which differ in their close relationship and pace of 
development" (Prymostka, Krasnova, Kulish, Nikitin, \& Shevaldina, 2020), as well as the fact that it can effectively perform all its functions, primarily distribution, information, liquidity support and others, only with the coordinated interaction of all of its participants - financial intermediaries in the form of banks, insurance companies, non-state pension funds, investment funds and others, the infrastructure subjects, including securities traders, organizers of an auction - stock exchanges, payment systems, depositories, etc., and financial regulators. In addition, an important role is played by the availability of investment-attractive and high-quality financial instruments, as well as the formed effective demand and supply of financial instruments, the ability to apply various risk management methods, including the use of derivatives. The basis for this is the formation of an appropriate regulatory framework that would reduce the level of speculative nature of the Ukrainian financial market.

\section{LITERATURE REVIEW}

"The financial system of the advanced countries develops according to two basic models - a bankbased system and a market-based system, depending on the level of protection of the rights of owners, investors and lenders" (Chernadchuk, Sukhonos, \& Shkolnyk, 2017).

Initially, the main arguments were that market-centric systems are more efficient due to greater flexibility and relative reduction in agency costs. However, in the classic work of Allen and Gale (2000), it has been proven that the answer to this question is not so clear. Although the authors tend to agree with the thesis of a relatively higher efficiency of the market-centric system in terms of its contribution to economic growth, they emphasize that this conclusion is the result of a positive analysis rather than normative. It's just that countries with the most developed financial systems are market-centric (primarily the United States and the United Kingdom), but this does not necessarily indicate the existence of a causal link.

At the theoretical level, scientists have reached a certain understanding. When comparing many national financial systems, it was found that both types have both advantages and disadvantages. On the one hand, many scholars, such as Gerschenkron (1962), Diamond (1984), Stiglitz (1985), Boyd and Prescott (1986), Bencivenga and Smith (1991), Bhide (1993), Stulz (2002), and many others, believed that a bank-centric financial system was superior to a market-centric one. According to this approach, banks perform the function of reducing information asymmetry and solve the problem of interim transaction costs and risks, and therefore have comparative advantages in terms of information collection, valuation of companies and ensuring relationships with companies (Gerschenkron, 1962; Opler, 1993; Rajan \& Zingales, 2003, Čihák, Demirgüç-Kunt, Feyen, \& Levine, 2012).

On the other hand, Holmstrom and Tirole (1993), Jansen and Murphy (1990), Booth and Thakor (1997), Wenger and Kaserer (1998), as well as many others take the opposite view, advocating the benefits of a market-centric system. It is rightly emphasized that the direct transfer of funds reduces agency costs. However, this increases the costs associated with information asymmetry. "The market-based methods often react differently, as their reactions to the actual market developments are more flexible" (Chovancová, Árendáś, Slobodník, \& Vozňáková, 2019).

However, Merton and Bodie (1995), and Levine (2002) believe that the level of provision of economic entities with financial services is a critical factor for economic development in general, rather than the structure of these services; they also emphasize the complementarity of banks and markets as producers of such services for households and companies.

Developing modern financial system in Ukraine is based on the privatization process, which was the basis of the formation of the country's stock market. This had both a positive and a negative effect on further development. In particular, the positive effect is in the fact that during the privatization, there was an exchange of privatization certificates for enterprises' shares, which formed the basis for the emergence of the stock market. It is specified that it was an "artificial" formation of the stock market, since the exchange of privatiza- 
tion certificates for the stock took place without a real movement of capital, and, therefore, from the very beginning the stock market did not fulfill its key function of transforming savings into an investment. At the same time, banking institutions developed rapidly, and given that the role of the banking system in the development of the economy was more understandable, including for the population, and taking into account highly skilled specialists from the National Bank of Ukraine, who developed the main legislative documents regulating the functioning of banks in Ukraine, the financial system model, based on banks as the key financial intermediaries, was historically developed.

\section{METHODOLOGY}

This study used statistical data on the share of assets of financial intermediaries in GDP, the relationship between the income level in the country and the share of bank assets in GDP, dynamics of loans and deposits in the Ukrainian banking system, dynamics of the structure of deposits and loans by currency, indicators of the asset structure of Ukrainian banks and all other indicators. The studied period is from 2007 to 2019. All data is taken from the websites of the NBU, the National Commission for State Regulation of Financial Services Markets and the International Monetary Fund.

The study includes the following stages: determining the share of assets of financial intermediaries in GDP, analysis of the loan and deposit ratio in the banking systems, analysis of non-performing loans by economic sectors, determining the dynamics of the number of banks in Ukraine, analysis of the structure of banks' assets, determining the dynamics of NPLs in terms of bank groups based on ownership.

\section{RESULTS}

To confirm the thesis about the signs of bank-centricity of the financial market in Ukraine, the share of assets of financial intermediaries in GDP was determined (Figure 1).

First of all, it is necessary to note a significant decrease in the share of assets of all financial intermediaries in Ukraine's GDP. During the analyzed period, their share significantly decreased nearly twice, from $85 \%$ in 2007 to $44 \%$ in 2019 . "The Ukrainian economy and its banking system, according to certain parameters, still do not correspond to the global dynamic processes of movement of monetary resources and capital, which slows down Ukraine's integration into the global economic space" (Kozmenko \& Korneev, 2014). Meanwhile, the steady downward trend in this indicator began to form in 2014 and was associated with political events, the outbreak of hostilities in eastern Ukraine, as well as the loss of control over the Autonomous Republic of Crimea. These events also led to a decrease in the country's GDP, as noted above. It should be noted that the maximum value of the share of financial intermediaries in the country's GDP was observed in 2008 for State Regulation of Financial Services Markets.

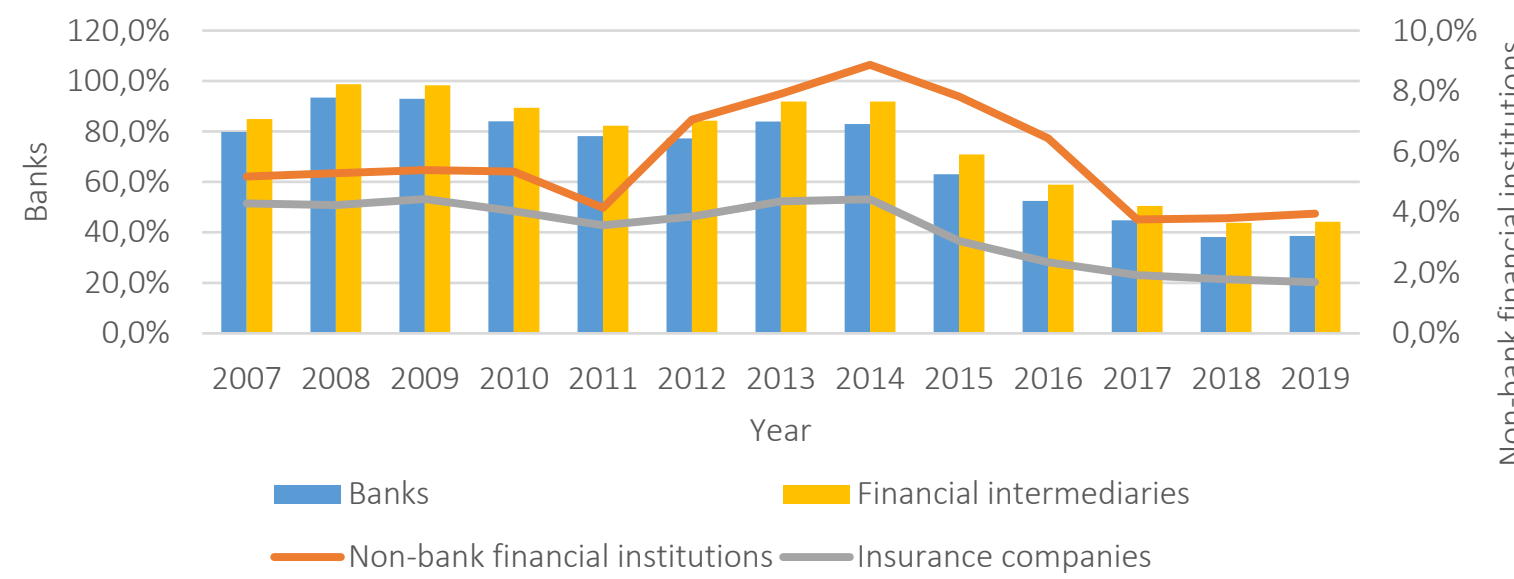

Figure 1. Share of financial intermediaries' assets in Ukraine's GDP 
and 2009 and amounted to almost 99\%. The bulk of financial assets belongs to banks, which determines the dynamics of assets of all financial intermediaries. The share of bank assets for the period decreased more than twice compared to 2007, and if we compare the value of 2019 (38.6\%) with the 2008 maximum value (93.5\%), then the decrease was more than 2.4 times. According to the International Monetary Fund 2017 data, the maximum share of bank assets in GDP (this year, the value of the indicator for Ukraine was more than $44 \%)$ was $256.63 \%$ in Hong Kong, while it ranked second in China (174.54\%), with a significant gap of more than $80 \%$.

It should be noted that there is a significant discrepancy in this indicator in European countries, because "financial development, global financial transformations have different manifestations in these countries" (Bulatova, Marena, Chentukov, \& Shabelnyk, 2020). We assumed that the share of bank assets as \% of GDP may be related to the level of income in the country. It should be noted that

in 2019 the classification of countries by income level was adjusted. However, the changes were not significant and therefore did not affect the grouping of analyzed countries. This hypothesis is being tested using European countries as an example. The grouping results are shown in Figure 2.

Analyzing the results, one can conclude that lower-middle-income economies, namely Ukraine and Moldova, show one of the lowest values of the share of bank assets in GDP, while upper-middle-income countries (Turkey, Bulgaria, Russia, Belarus and Romania) show values below the average (84\%) in the sample.

The largest discrepancy in the analyzed indicators is observed precisely among the countries that are classified as high-income economies, which are the majority of European countries. The range of variation of the indicator for this group is more than $120 \%$ (the maximum value is $172.28 \%$ for Denmark and the minimum value is $44.63 \%$ for Lithuania). At the same time, for this group of countries, it

Source: Author's calculations based on the International Monetary Fund data.

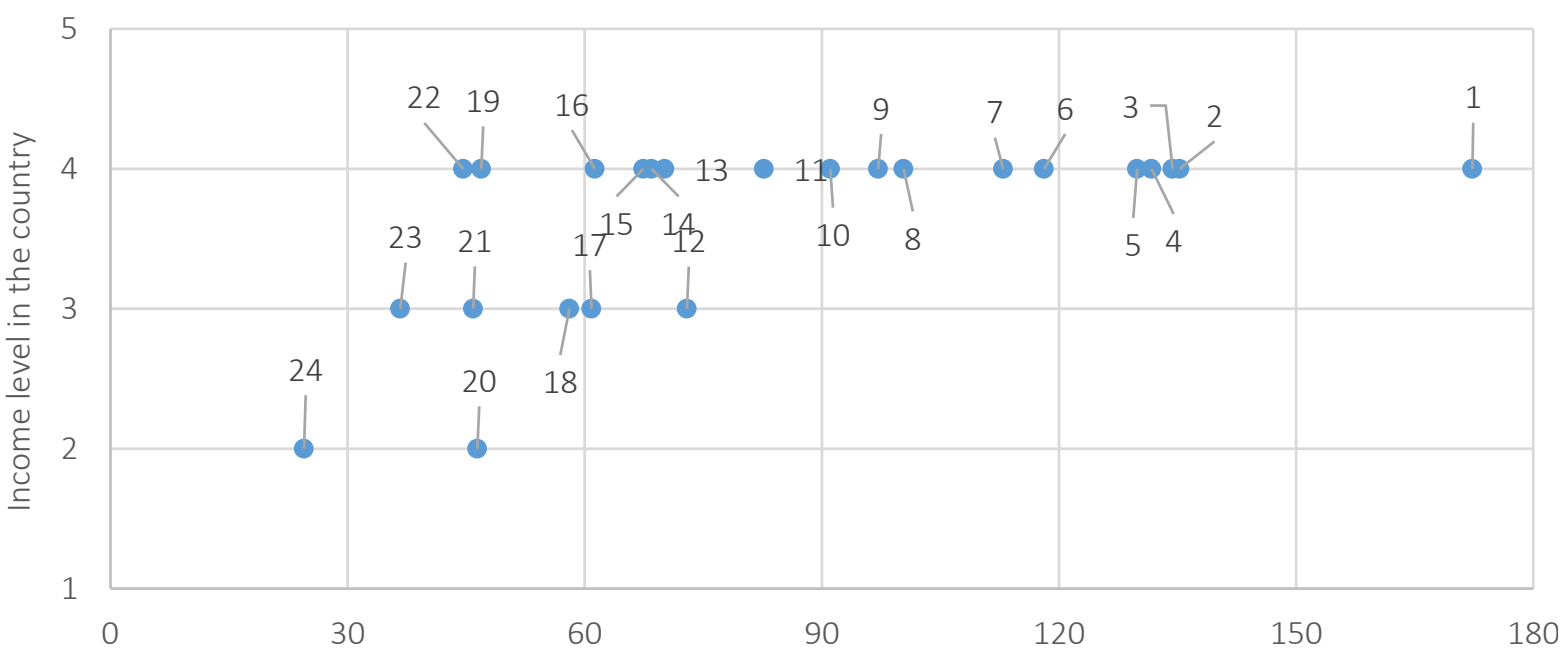

Share of bank assets as a \% of the country's GDP

\begin{tabular}{|c|c|c|c|c|c|c|c|}
\hline Denmark & 1 & France & 7 & Poland & 13 & Latvia & 19 \\
\hline Sweden & 2 & Finland & 8 & Slovakia & 14 & Ukraine & 20 \\
\hline Norway & 3 & Austria & 9 & Estonia & 15 & Belarus & 21 \\
\hline The UK & 4 & Germany & 10 & Czech Republic & 16 & Lithuania & 22 \\
\hline Spain & 5 & Croatia & 11 & Bulgaria & 17 & Romania & 23 \\
\hline Italy & 6 & Turkey & 12 & Russian Federation & 18 & Moldova & 24 \\
\hline \multicolumn{4}{|c|}{ Low-income countries $=1$} & \multicolumn{4}{|c|}{ Upper-middle-income countries $=3$} \\
\hline \multicolumn{4}{|c|}{ Lower-middle-income countries $=2$} & \multicolumn{4}{|c|}{ High-income countries $=4$} \\
\hline
\end{tabular}

Figure 2. The relationship between the income level in the country and the share of bank assets in GDP 
should be noted that, as a rule, below average values are shown by countries with relatively new financial markets, which belong to frontier markets, namely Lithuania, Latvia, Estonia, and Slovakia. A special case can be noted in Poland, because, on the one hand, the share of bank assets in GDP is below average (70.11\%), but the country's financial market belongs to a developed market, along with other countries such as the UK, Germany, France and others. On the other hand, this situation may explain the lower activity of banks, since the main segment of the financial market is not the banking sector, but the stock segment with a strong international stock market, which is primarily represented by the Warsaw Stock Exchange. So, in general, it is possible to confirm a certain relationship between the analyzed indicators, but not strong enough. The calculated pairwise correlation coefficient (0.59) indicates the presence of a relationship, but not significant enough.

Given that banks are the main financial intermediaries in Ukraine, the process of forming banks' capital on the one hand through the formation of a deposit portfolio, and on the other, by lending to both business entities and the population, becomes important.

Analysis of the loan-to-deposit ratio in the banking system of Ukraine shows that the deposit base was far smaller than the size of loans throughout the analyzed period. But since 2018, the gap between the volume of loans and deposits has gradually decreased, and since November 2019, the situation has changed to the opposite, namely, the volume of deposits exceeded the volume of loans by UAH 1,275 million. On the one hand, the coordination of the deposit and credit base is a positive phenomenon, but the excess of deposits over loans indicates that the demand for credit resources in the economy decreases.

On the other hand, the use of loans by economic entities is extremely limited, since the profitability of operating activities of economic entities is much lower than the interest rate on loans (Figure 3). This situation means that for businesses, the use of loans automatically leads to unprofitable activities, since the profit from operating activities is not enough to reimburse the financial costs incurred by organizations in servicing debt.

Analysis of the dynamics of the rate on loans shows that the interest rate on loans to business entities is much lower than the rate on loans to households. Thus, according to the NBU, the average value of interest on loans to businesses for the analyzed period is $14.82 \%$, while the magnitude of variation is $4.9 \%$, and there is a significant unevenness in the values of indicators. The average value of interest rate on loans to households is $26.15 \%$, that is, 1.7 times higher than the rate on loans to businesses. It should also be noted that the interest rate on loans to individuals has a steady upward trend. If in 2007 the interest rate was $15.6 \%$, then in 2019 it almost doubled to $32 \%$. On the other hand, there is no cardinal difference in deposit rates.

A comparison of the structure of deposits and loans made it possible to draw a conclusion about

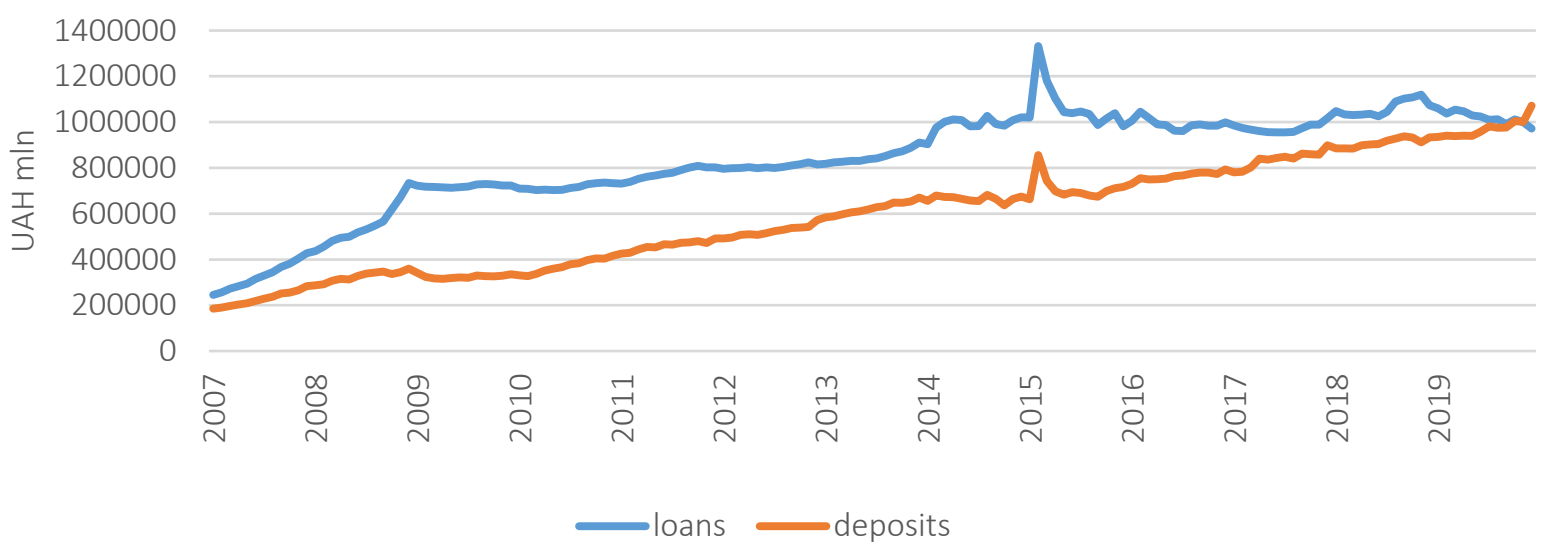

Figure 3. Dynamics of loans and deposits in the Ukrainian banking system 
\% on deposits non-financial corporation — \% on loans non-financial corporation

\% on deposits households

Operating profitability, \%

\section{Figure 4. Dynamics of rates on deposits and loans and operating profitability of economic entities}

the structural mismatch. Based on the NBU data on the volume of deposits and loans formed by basic sectors of the economy for the period from 2007 to 2019, the average structure of deposits and loans was calculated (Figure 4).

Funds raised from the population are the main source of formation of the banks' deposit base. This situation is stable compared to other sectors

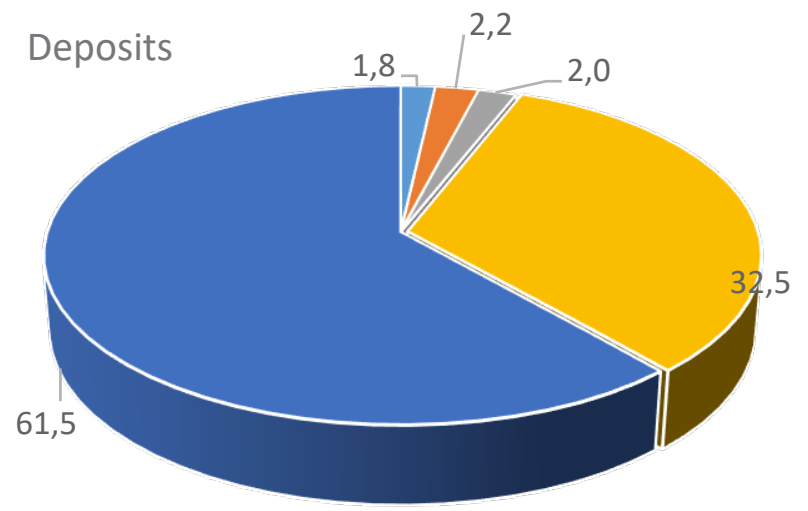

- Insurance corporations and pension funds

- Other financial corporations

- Public administration sector

- Non-financial corporations

- Households and non-profit organizations and has no significant deviations between the minimum $(53.7 \%)$ and maximum (68\%) values. Non-financial corporations form an average of $32.5 \%$ of the deposit base. Indicative of the state of Ukraine's financial system is also the indicator of the share of insurance companies and private pension funds in the deposit structure. They account for only $1.8 \%$, which characterizes them as rather weak financial intermediaries. At the same time,

Figure 5. Structure of deposits and loans by economic sectors, the averaged 2007-2019 value 
in countries with developed financial markets, insurance companies and private pension funds are among the main institutions that provide the economy with long-term financial resources by, among other things, placing them on deposit accounts with banks. And given the fact that bank deposits are one of the main assets of insurance companies and taking into account legal restrictions on the placement of assets, these intermediaries accounted for 35\% in 2019.

In the context of the structure of loans by sectors of the economy, the main share among the sectors is occupied by non-financial corporations, that is, economic entities of the real sector. For the analyzed period, their share in the averaged value is more than $70 \%$, which is more than twice the deposit base they formed. Thus, we can conclude that the population's savings is the main sector that provides the economy with financial resources.

Figure 5 shows the dynamics of integrated indices of structural changes by sector of the economy.
The presented graphs allow drawing conclusions about significant structural mismatches between the sectors of the economy, both in terms of deposits and loans. In particular, the greatest structural changes in the deposit base occurred in 2008, and they were primarily provoked by insurance companies and private pension funds, caused by the effects of the global financial crisis. On the other hand, fluctuations in deposits are almost insignificant compared to fluctuations in structural changes in loans.

Structural changes in loans are much larger, with the greatest fluctuations observed between 2007 and 2009. This happened due to the crisis in the Ukrainian economy, which was largely a consequence of the global financial crisis of 2007-2008.

Given the high level of dollarization of the Ukrainian economy, it is important to study the structure of deposits and loans in the context of currencies in which they were formed. A high level of dollarization has negative consequences for
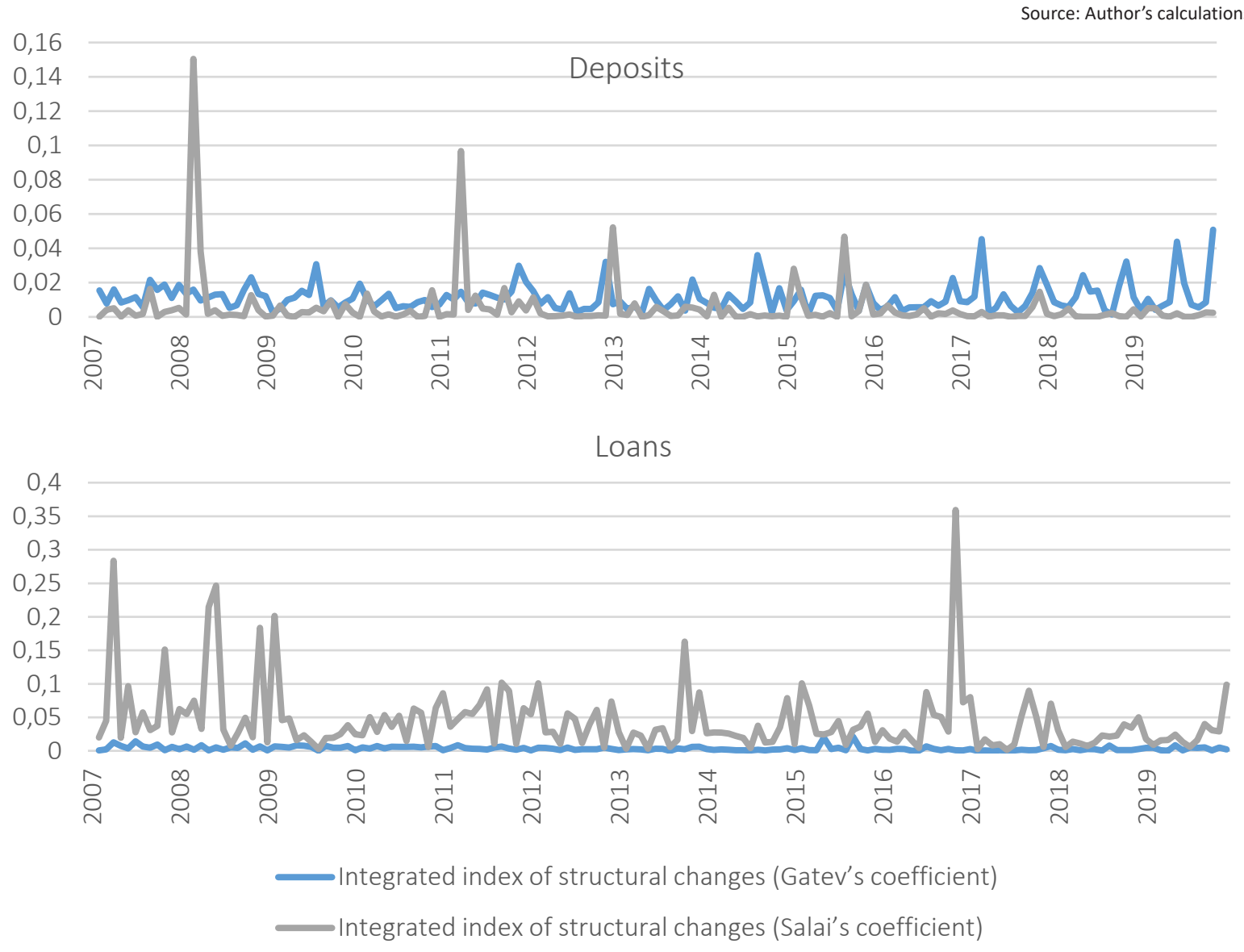

Figure 6. Dynamics of integrated indices of structural changes by sectors of the economy 
the economy, which primarily manifest themselves in a decrease in the effectiveness of monetary policy, as well as a significant dependence on the influence of external factors. The main factors of dollarization are inflation, the weakness of the national currency due to incomplete supply of liquid commodity mass, exchange rate fluctuations, distrust of the population in their own currency, unstable political and economic situation in the country, the threat of social upheaval (Ganusyk, 2014).

Figure 6 shows the dynamics of the structure of deposits and loans between 2007 and 2019 by main currencies, namely, the hryvnia, the US dollar and the euro. These three currencies are the main ones in the structure, the rest make up a small share. So, in the structure of deposits, on average for the analyzed period, other currencies account for $0.48 \%$. A more detailed analysis of the structure shows that the structure of the currency as a whole for the analyzed period has undergone significant fluctuations, which is confirmed by the calculated integrated indices of structural changes (Figure 7).

It should be noted that there have been significant changes in the currency structure of deposits and loans due to the use of the Russian ruble. Thus, at the beginning of the analyzed period, the share of the Russian ruble was only $0.02 \%$, and this indicator remained until 2008 and 2009 with slight fluctuations from $0.02 \%$ to $0.4 \%$. From mid-2009 to March 2014, the share of the Russian ruble grew steadily, and in March 2014 it amounted to $0.21 \%$. This was followed by a steady decline in the share of this currency in deposits, and at the end of 2019, their share was $0.03 \%$.

The reasons for such structural changes are political events and the aggression of the Russian Federation, as a result of which banks with Russian capital were closed and left the market. The dynamics of the Gatev index confirms these
70

60

50

40

30

20

10

0

Loans

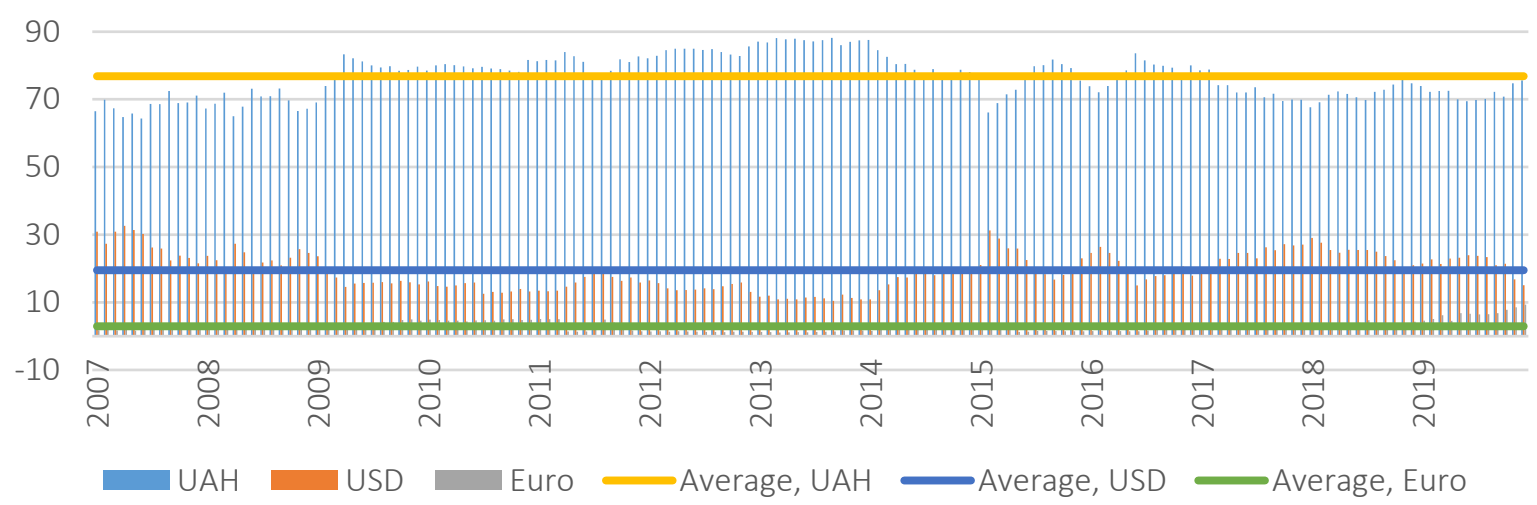

Figure 7. Dynamics of the structure of deposits and loans by currency 

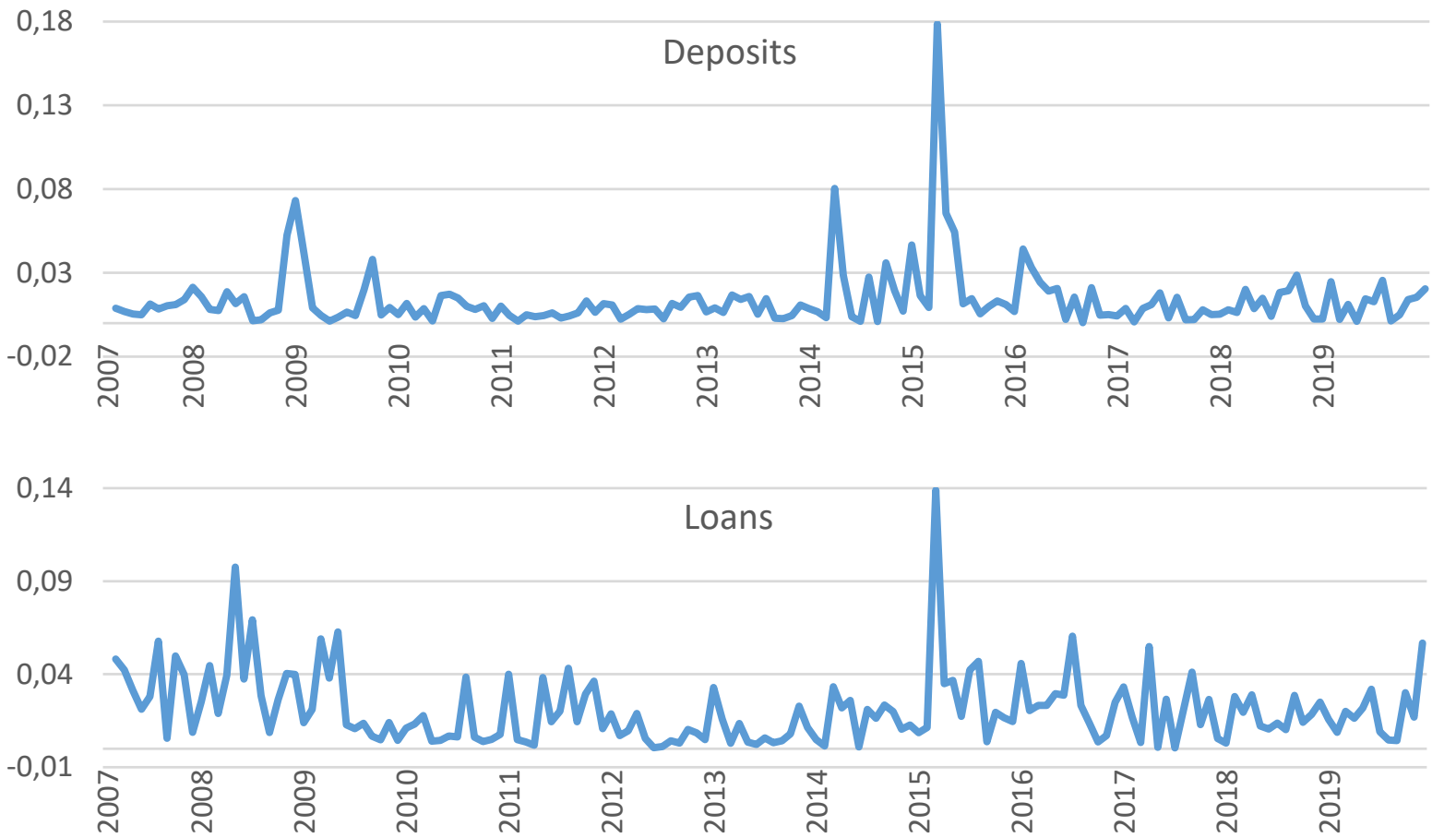

Figure 8. Dynamics of integrated indices of structural changes (Gatev coefficient) in terms of currencies

conclusions, therefore, the greatest structural changes occurred during these periods. It should also be emphasized that since 2016, the share of deposits in hryvnia has been gradually increasing, while the share in dollar terms has been decreasing, which confirms the gradual restoration of confidence in the national currency.

As for the dynamics of the loan structure in terms of foreign currency, the share of national currency is much higher than in other currencies. Compared with deposits (average value 52\%), the average value of loans issued in hryvnia for the analyzed period amounted to more than $75 \%$. At the same time, unlike deposits, loans in Russian rubles were not issued during the entire analyzed period. The share of loans in US dollars in the averaged value for the analyzed period is half (19.5\%) compared with the share of deposits (almost 38\%). It is also worth noting that before the beginning of 2009 loans were also issued in foreign currencies other than the US dollar and the euro, but since 2010 their share has also dropped to 0 .

Analysis of Gatev's integrated index of structural changes allows drawing conclusions about the consistency of the dynamics of currency fluctua- tions for certain periods. The largest coincidences were in 2009 and 2015, primarily due to political factors (2015) and the consequences of the 2008 (2009) global financial crisis.

The bank-centric nature of the financial system of Ukraine is determined not only by the significant predominance of bank assets in the total financial assets of the economy, but also by the role that banks play in other segments of the financial system. Banks play a leading role in the functioning of the stock market both as securities traders and participants in payment systems and as depository institutions. Thus, Blagun (2019) conducted an indepth analysis of the current state of the Ukrainian financial market infrastructure and, in particular, investigated the role of banks in its development. About 60 banks are licensed to trade in securities. Given that at the end of 2019, 75 banks operated in Ukraine, this means that almost all of them are participants in operations on the Ukrainian stock market.

To assess the state of the banking system of Ukraine, indicators characterizing the quality of banks' loan portfolios are of great importance. In particular, what is the share of non-perform- 
ing loans in banks' portfolios, since a significant increase in debt is a negative phenomenon for a bank, as debt affects the bank's liquidity, which can lead to insolvency of a banking institution and its bankruptcy. The presence of problem loans (non-performing assets) requires banks to form significant reserves (Kots, Ilchuk, \& Karpin, 2018).

Analysis of non-performing loans by economic sectors for the period from 2018 to 2019 (Figure 8) shows that the largest share of NPLs is formed in the corporate sector of the economy, it accounts for more than $50 \%$ and this value is quite stable. The share of loans to individuals is also quite significant and averages $46.57 \%$ over two years, which is $10 \%$ lower than the same indicator for the corporate sector of the economy. Given that in 2019, the largest share in the structure of loans - more than $70 \%$ - fell on loans to the corporate sector, especially to non-financial corporations, it becomes clear that the bulk of outstanding loans are loans from real sectors of the economy. There is a positive trend in loans to individuals, as the share of outstanding loans is gradually decreasing. If at the beginning of 2018 the value of this indicator was at the level of $53.51 \%$, then by the end of 2019 the indicator decreased to 37.22 , that is, the reduction is more than $30 \%$. As for other sectors, given their small share in the structure of the loan portfolio as a whole, their value does not significantly affect the state of the banking system.
Analyzing the indicators of the Ukrainian banking system from the point of view of owners, it can be noted that state-owned banks account for the largest share in the structure of assets. In general, during the analyzed period, there have been significant changes in the Ukrainian banking system both in the number of banks and in the structure of their ownership (Figure 9).

Thus, at the beginning of the analyzed period, the total number of banks in Ukraine was 175 , while the vast majority of them (128) were domestic banks. As of 2019, the NBU, namely the Committee on Supervision and Regulation of Banking, Oversight of Payment Systems, identified three groups of banks, namely:

1) banks with a government (state) share are banks in which the state directly or indirectly owns more than $75 \%$ of the authorized capital of the bank;

2) banks of foreign banking groups are banks whose controlling stakes are owned by foreign banks or foreign financial and banking groups;

3) private capital banks are banks in which among the ultimate owners of significant participation are one or more private investors who directly and/or indirectly own at least $50 \%$ of the authorized capital of the bank.

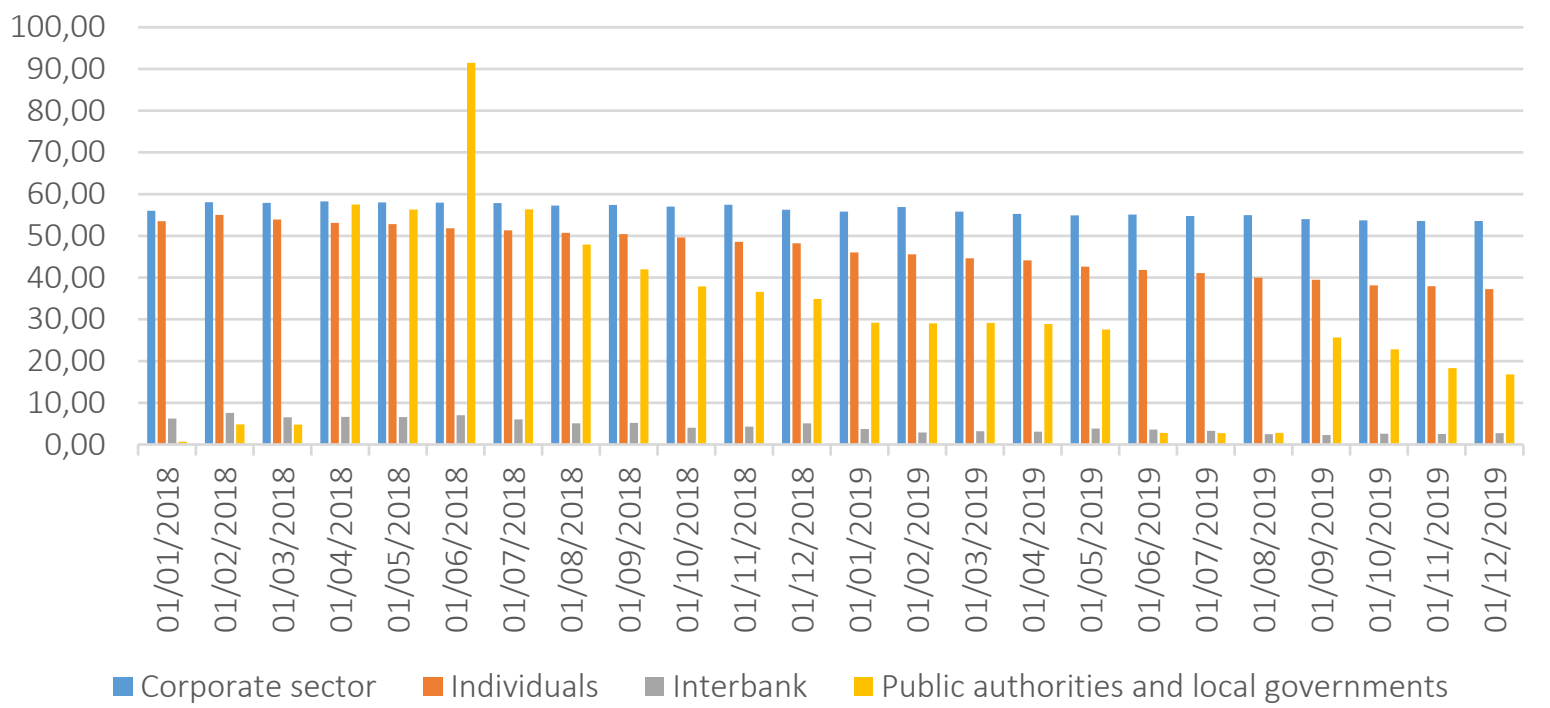

Figure 9. Dynamics of NPLs by sectors of the Ukrainian economy 


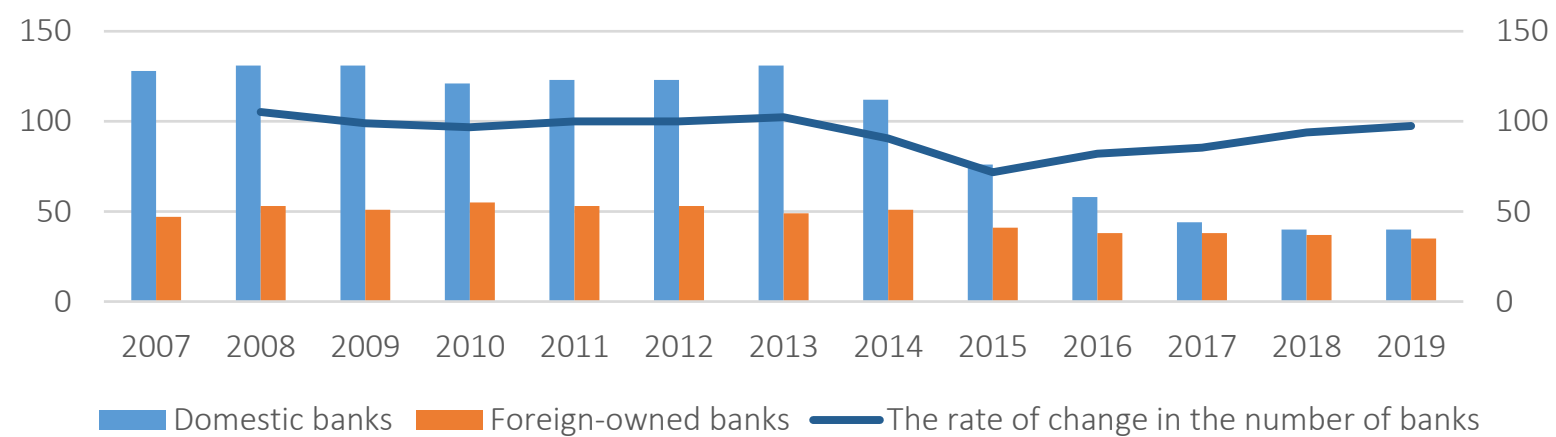

Figure 10. Dynamics of the number of banks in Ukraine

In 2013, 180 banks operated in Ukraine, which was the largest number. Since 2014, the number of banks has gradually decreased. This was due to many reasons. First, as a result of political events and the loss of control over the Autonomous Republic of Crimea, as well as in the east of Ukraine in Donetsk and Luhansk regions, some banking institutions were lost. Also, banks have lost part of their branch network, resulting in a significant reduction in bank assets, as was mentioned above. Second, starting from this period, the NBU began to pursue a policy of "rehabilitation" of the banking system, as a result of which a significant number of banks were withdrawn from the market. As a result of this policy, the number of banks in Ukraine sharply decreased and at the end of 2019 amounted to 75 , including 40 banks with domestic capital, i.e. the number of domestic banks fell by more than three times. It should be noted that the number of foreign-owned banks also decreased, but not so significantly. Compared to 2007, the number of banks decreased by 12 institutions, but if we analyze in comparison with 2010, when there was the largest number of banks with foreign capital - 55, the reduction was $35 \%$. A significant number of banks with foreign participation that were withdrawn from Ukraine were banks with Russian capital. On the other hand, over the same period, against the background of a decrease in the total number of banks, including those with foreign capital, the number of banks with $100 \%$ capital increases from 14 to 23 . At the end of 2019, the ratio between banks with domestic capital and banks with foreign capital was almost 1 to 1 (40 to 35 , respectively).

Nowadays, it is difficult to assess the consequences of the NBU's policy of "cleansing" the banking sys- tem, since, on the one hand, the liquidation of insolvent banks and banks that violated Ukrainian law should have a positive impact on the transparency of the banking system. "Bank transparency as well as any other type of business is one of the main priorities that closely correlates with the concept of sustainable development and the achievement of its goals" (Makarenko, Yelnikova, Lasukova, \& Barhaq, 2018). On the other hand, an excessive reduction in the number of participants in the banking sector may lead to a deterioration of the competitive environment and conditions for the provision of banking products (Zolotareva \& Galaganov, 2017).

Analysis of the structure of banks' assets, taking into account their owners, shows that at the end of the analyzed period the share of state-owned banks' assets increased significantly (Figure 10). The share of state-owned banks' assets increased sharply in 2016 as a result of the nationalization of Privatbank. Thus, since 2016, the share of assets of state-owned banks in the total assets of the banking system is more than $50 \%$. This situation also confirms the public orientation of the financial system of Ukraine in terms of its banking sector.

At the same time, the total number of state-owned banks at the end of 2019 was five institutions: Ukreximbank, Sberbank, Privatbank, Ukrgasbank and the Settlement Center. The Settlement Center has a very specific status and is not a bank in the full sense of the word, since its full name is Public Joint-Stock Company Settlement Center for servicing contracts in financial markets. Of all banking services, this institution provides services for opening current/correspondent accounts, open- 


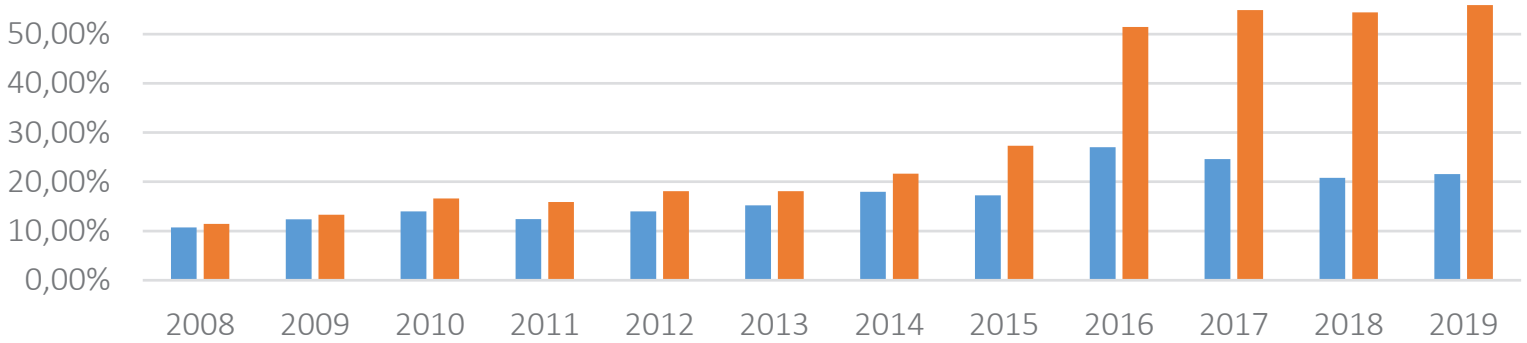

Figure 11. Indicators of the asset structure of Ukrainian banks

ing accounts for settlements, carries out cash settlements under securities agreements on a basis of the "Delivery versus payment" principle and makes payments of income accrued on securities. The main services of the Settlement Center are clearing operations, which include opening and maintaining clearing accounts/sub-accounts, accounting for the rights and obligations of clearing participants under securities agreements, and netting through the Central Counterparty. Having the status of a bank, this institution does not carry out classical banking operations and does not form a deposit and loan portfolio. Based on this, in fact, there are actually four banks with state participation, that is, given that at the end of 2019 the total number of banks with domestic capital was 40 institutions, four of them are banks with state participation (10\% of domestic banks and 5\% of the total) that control more than half of all assets of the banking system (Figure 12).

In this situation, the quality of the loan portfolios of these banks is important, since the presence of a significant share of non-performing loans largely determines the stability and efficiency of the banking system as a whole.

In addition, the activities of these banks have a direct impact on the stock market, since the state, represented by the Ministry of Finance of Ukraine, recapitalizes them almost every year by placing issued shares and issuing domestic government bonds, thereby increasing public debt.

An analysis of these indicators shows that banks with a state share have a very low quality of the

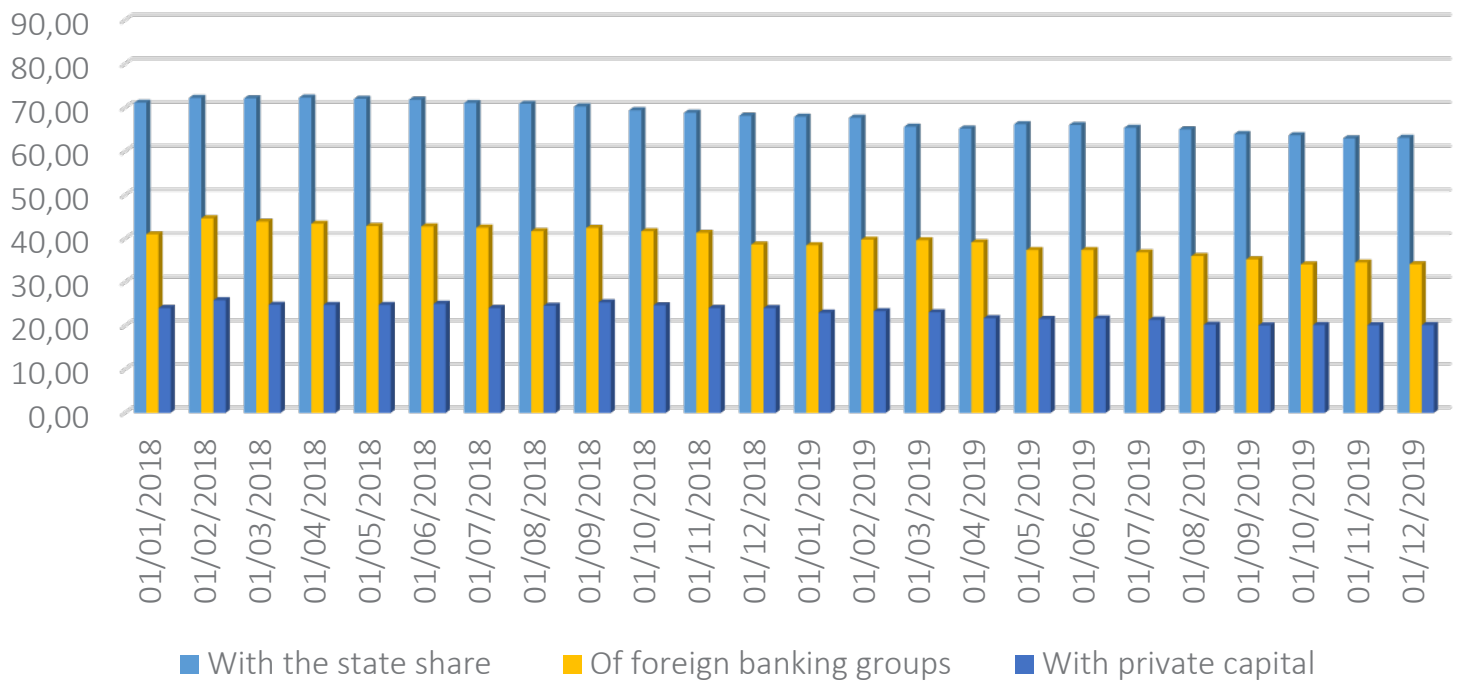

Figure 12. Dynamics of NPLs in terms of bank groups on the basis of ownership 
loan portfolio. On average, in 2018-2019, the share of non-performing loans was more than $68 \%$, that is, given the fact that these banks control more than $50 \%$ of all assets in the banking system, then they significantly reduce its efficiency and functioning. At the same time, foreign-owned banks also have a significant share of NPLs in their portfolios - on average, almost $40 \%$, but this indicator is positive, in particular, it decreased to $34 \%$, compared to the beginning of 2018. Banks with domestic capital show the lowest value of NPLs - $23 \%$ on average. Meanwhile, the value of this indicator could have been much higher, given that about $50 \%$ of non-performing loans as of early 2018 were concentrated in the portfolios of banks recognized as insolvent and withdrawn from the market.

Given the situation with the loan portfolio of stateowned banks, it is worth considering their condition from the point of view of these banks. Thus, according to the NBU and the Ministry of Finance of Ukraine, the amount of NPLs of Oschadbank at the end of 2018 amounted to UAH 93.6 billion (67\%), and for the year it decreased by UAH 20.6 billion and amounted to UAH 77.3 billion of the size of the loan portfolio. A significant part of these non-performing assets are loans issued prior to 2014, mainly in territories not controlled by Ukraine. According to the Ministry of Finance of Ukraine, $94 \%$ of the volume of these loans are loans to legal entities. The situation is quite similar with Ukreximbank; the share of NPLs at the end of 2018 was $59 \%$ and at the end of 2019 it decreased by only $1 \%$, amounting to UAH 14.2 billion. As in the case of Oschadbank, the largest share of NPLs was also issued before 2014. It should be noted that this bank has a loan portfolio that is formed only by legal entities.

Of all the banks with state participation, the best situation was in Ukrgasbank, since in 2018 the share of non-performing loans was only $17 \%$, which was UAH 8.8 billion, but unlike other banks, in 2019 the quality of the loan portfolio deteriorated, as there was a slight increase in the share of NPLs - by $3 \%$, amounting to UAH 0.4 billion.

The situation in Privatbank is not typical. This bank has the worst loan portfolio structure, because, firstly, the volume of NPLs in 2019 amounted to UAH 239.2 billion, and, secondly, it was more than $80 \%$ of the total loan portfolio. Unlike other banks, non-performing loans in this bank are loans to legal entities that are related to the Privat Group and the former owners of the bank.

It should also be noted that in the loan portfolios of these banks, formed by legal entities, the share of loans classified as Class 1 is minimal and ranges from $0.4 \%$ (Oschadbank) to $4.3 \%$ (Ukreximbank). This situation forces banks to form significant capital reserves to cover credit risks. This, in turn, leads to the need for recapitalization procedures, which are periodically carried out by the Ministry of Finance of Ukraine, issuing domestic government bonds and converting the capital into shares of these banks.

\section{CONCLUSION}

Thus, having analyzed the functioning of the banking system of Ukraine, one can conclude that, first, it is the main segment of the financial system in terms of redistributing financial resources in the economy. Thus, it can be argued about the bank-centric nature of Ukraine's financial system. Second, the banking system of Ukraine largely depends on the state of public finances, on the one hand, and by itself has a significant impact on the state of public finances. Third, in the banking system of Ukraine during the analyzed period there were quite significant changes in the number of banks and their structure on the basis of ownership. Thus, since 2016, the share of assets of state-owned banks in the total assets of the banking system is more than $50 \%$. This situation also confirms the public orientation of Ukraine's financial system in terms of its banking sector. Fourth, the quality of banks' assets is quite low, which does not allow the banking system to be defined as stable and efficient enough. An analysis of these indicators shows that banks with a state share have a very low quality of the loan portfolio. On average, in 2018-2019, the share of non-performing loans was more than $68 \%$, that is, given the fact that these banks control more than $50 \%$ of all assets in the banking system, then they significantly reduce its effi- 
ciency and functioning. Thus, analyzing the information obtained, one can conclude about the formation of a bank-centric model of the Ukrainian financial market. It was also concluded that the basis for building the domestic financial market should be banks that have the ability to influence the country's economic growth, at least until the stock market begins to function effectively. This should determine the appropriate economic contour of the Ukrainian financial market model.

\section{AUTHOR CONTRIBUTIONS}

Conceptualization: Serhiy Frolov, Fathi Shukairi.

Data curation: Fathi Shukairi.

Formal analysis: Fathi Shukairi.

Methodology: Serhiy Frolov.

Project administration: Serhiy Frolov, Fathi Shukairi.

Supervision: Serhiy Frolov.

Validation: Serhiy Frolov.

Visualization: Fathi Shukairi.

Writing - original draft: Serhiy Frolov, Fathi Shukairi.

Writing - reviewing \& editing: Serhiy Frolov, Fathi Shukairi.

\section{REFERENCES}

1. Allen, F., \& Gale, D. (2000) Comparing Financial Systems. Cambridge, MA: MIT Press.

2. Bencivenga, V., \& Smith, B. D. (1991). Financial Intermediation and Endogenous Growth. Review of Economic Studies, 58(2), 195209.

3. Bhide, A. (1993). The Hidden Costs of Stock Market Liquidity. Journal of Financial Economics, 34(1), 1-51. Retrieved from https://www.jstor.org/ stable/2297964?seq=1

4. Blagun, I. I. (2019). Infrastructure of the Ukraine's Financial Market: State and Development Prospects. Accounting and Finance, 4(86), 63 69. Retrieved from https://journals.indexcopernicus.com/api/file/ viewByFileId/775346.pdf

5. Boot, A., \& Thakor, A. V. (1997). Financial System Architecture. Review of Financial Studies, 10(3), 693-733. Retrieved from https:// pdfs.semanticscholar.org/e9b8/54 11815577ebbb0e62456c5e7a4b07 1207f4.pdf

6. Bulatova, O., Marena, T., Chentukov, Yu., \& Shabelnyk, T. (2020). The impact of global financial transformations on the economic security of Central and Eastern
European countries. Public and Municipal Finance, 9(1), 1-13. http://dx.doi.org/10.21511/ pmf.09(1).2020.01

7. Chernadchuk, V., Sukhonos, V., \& Shkolnyk, I. (2017). The notion and content of financial system in the context of financial law of Ukraine. Problems and Perspectives in Management, 15(2-1), 234245. http://dx.doi.org/10.21511/ ppm.15(2-1).2017.07

8. Chovancová, B., Árendáš, P., Slobodník, P., \& Vozňáková, I. (2019). Country risk at investing in capital markets - the case of Italy. Problems and Perspectives in Management, 17(2), 440-448. http://dx.doi. org/10.21511/ppm.17(2).2019.34

9. Čihák M., Demirgüç-Kunt A., Feyen, E., \& Levine R. (2012). Benchmarking financial systems around the world (Police Research Working Paper No. 6175). Washington, DC: World Bank. Retrieved from https:// www.researchgate.net/publication/255697804_Benchmarking_Financial_Systems_Around_ the_World

10. Diamond, D. (1984). Financial Intermediation and Delegated Monitoring. Review of Economic Studies, 51(3), 393-414. https://doi. org/10.2307/2297430
11. Ganusyk, Yu. B. (2014).

Dolaryzatsiia ekonomiky Ukrainy ta ii vplyv na inflyatsiyni protsesy [Dollarization of Ukraine's economy and its impact on inflation]. AMSU Bulletin. Economics Series, 1(51), 29-39. Retrieved from http://nbuv.gov.ua/UJRN/ vamsue_2014_1_7

12. Gerschenkron, A. (1962). Economic Backwardness in Historical Perspective. Cambridge, MA: Harvard.

13. Goldsmith, R. (1969). Financial Structure and Development. New Haven, CT: Yale University Press.

14. Holmstrom, B., \& Tirole, J. (1993). Market Liquidity and Performance Monitoring. Journal of Political Economy, 101(4), 678-709. Retrieved from https://www.jstor. org/stable/2138744

15. Jansen, M. C., \& Murphy, K. J. (1990). Performance Pay and TopManagement Incentives. Journal of Political Economy, 98(2), 717-738.

16. Kots, O. O., Ilchuk, P. G., \& Karpin, O. V. (2018). The Establishment of Problem Loans and Management of Banks. Global and National Economic Problems, 22, 807-810. Retrieved from http://global-national.in.ua/archive/22-2018/152.pdf 
17. Kozmenko, S., \& Korneev, M. (2014). Periodization of financialization process of economics: Domestic and foreign contexts. Economic Annals-XXI, 9-10(1), 73-76. Retrieved from https://www.researchgate.net/ publication/292485726_Periodization_of_financialization_ process_of_economics_Domestic_and_foreign_contexts

18. Levine, R. (2002). Bank-based or Market-based Financial Systems: Which Is Better? Journal of Financial Intermediation, 11(4), 398-428. https://doi.org/10.1006/ jfin.2002.0341

19. Makarenko, I., Yelnikova, Yu., Lasukova, A., \& Barhaq, A.R. (2018). Corporate social responsibility of financial sector institutions in the light of sustainable development goals financing: the role of banks and stock exchanges. Public and Municipal Finance, 7(3), 1-14. http://dx.doi.org/10.21511/ pmf.07(3).2018.01

20. Merton, R. C., \& Bodie, Z. A. (1995). Conceptual Framework for Analysing the Financial Environment. The Global Financial System: A Functional Perspective. Boston, MA: Harvard Business School, 3-31.

21. Nikolyshyn, I. Y., \& Zizyak, N. V. (2014). Rol ta znachennia finansovoho rynku $\mathrm{v}$ finansovii systemi Ukrainy [The role and importance of the financial market in the financial system of Ukraine]. A Young Scientist, 7(10), 53-55. Retrieved from http://nbuv.gov.ua/UJRN/

molv_2014_7\%282\%29 14

22. Opler, T. C. (1993). Controlling Financed Distress Costs in Leveraged Buyouts with Financial Innovations. Financial Management, 22(3), 79-90. Retrieved from https://www.jstor.org/ stable/3665929

23. Prymostka, L., Krasnova, I., Kulish, G., Nikitin, A., \& Shevaldina V. (2020). Modeling the segment interactions of Ukraine's financial market. Investment Management and Financial Innovations, 17(2), 101-112. http://dx.doi. org/10.21511/imfi.17(2).2020.09

24. Rajan, R. G., \& Zingales, L. (1998). Which Capitalism? Lessons from the East Asian Crisis. Journal of Applied Corporate Finance, 11(3), 40-48. Retrieved from https://pdfs. semanticscholar.org/9552/91668 690ed1946f87d24d64640e7e38cf aeb.pdf

25. Rajan, R., \& Zingales, L. (2003). Banks and markets: changing character European finance (NBER Working Paper, 9595). Retrieved from https://ideas.repec.org/p/ nbr/nberwo/9595.html

26. Slav'yuk, R., Shkvarchuk, L., \& Kondrat, I. (2017). Financial market imbalance: reasons and peculiarities of occurrence in Ukraine. Investment Management and Financial Innovations, 14(11), 227-235. http://dx.doi. org/10.21511/imfi.14(1-1).2017.09

27. Stetsko, M. V. (2016). Finansovyi rynok Ukrainy u konteksti hlo- balnoi konkurentospromozhnosti [Financial market of Ukraine in the context of global competitiveness]. Economic Analysis, 25(1),158-168. Retrieved from http://dspace.tneu.edu.ua/handle/316497/8371

28. Stiglitz, J. E. (1985). Credit Markets and the Control of Capital. Journal of Money, Credit and Banking, 17(2), 133-152. Retrieved from https://www.jstor. org/stable/1992329

29. Stulz, R. (2002). Financial Structure, Corporate Finance and Economic Growth. In A. Demirgüç-Kunt, \& R. Levine (Eds.), Financial Structure and Economic Growth: Cross-Country Comparisons of Banks, Markets, and Development (pp. 143-188). Cambridge, MA: MIT Press.

30. Wenger, E., \& Kaserer, C. (1998). The German System of Corporate Governance: A Model Which Should Not Be Imitated. In S. W. Black, \& M. Moersch (Eds.), Competition and Convergence in Financial Markets: The German and Anglo-American Models (pp. 41-78). N. Y.: North Holland.

31. Zolotareva, O. V., \& Galaganov, V. O. (2017). Suchasnyi stan ta perspektyvy rozvytku bankivskoi systemy Ukrainy [Current state and prospects of development of the banking system of Ukraine]. Problems of Economics and Political Economy, 1, 83-98. Retrieved from http://nbuv.gov.ua/UJRN/ pepe_2017_1_5 